\title{
Food Security, Food Sovereignty, and Indigenous Knowledge
}

\author{
Akin Ogundiran
}

Published online: 9 September 2019

(C) Springer Science+Business Media, LLC, part of Springer Nature 2019

On August 13 this year, President Muhammadu Buhari of Nigeria directed the country's central bank to stop providing foreign exchange to businesses seeking to import food into the country. This directive, according to the president's spokesperson, complements the government's ongoing efforts to boost agricultural production, reduce dependence on food imports, and diversify the domestic economy (AgroNigeria 2019). The amount of money that Africa's most populous country and largest economy spends on food imports - mostly grains and livestock products - has been rising for decades. It rose from nearly $\$ 2.9$ billion in 2015 to $\$ 4.1$ billion in 2017 , according to Nigeria's National Bureau of Statistics. The foreign currencies used for these purchases could be saved or spent on critical infrastructures for economic development, education, and health care. Nigeria is not alone in using its hard-earned foreign exchange for food imports despite its vast land resources. It is a pervasive problem in Africa. The continent's annual food import bill in 2017 stood at about $\$ 35$ billion, and this is estimated to climb to $\$ 110$ billion by 2025 if the trend is not reversed with decisive and effective food policy (Shaban 2017). This hefty bill of food imports does not, however, subsidize local food consumption. Rather, it supports local importers and foreign businesses. It should, however, be noted that the food import share represents less than $5 \%$ of per capita income (GDP per

A. Ogundiran $(\bowtie)$

Department of Africana Studies, UNC Charlotte, Charlotte, NC 28223, USA

e-mail: ogundiran@uncc.edu capita) in Africa (Rakotoarisoa et al. 2012). That is, African countries rely on domestic production for feeding their people. But, due to population increase and low agricultural productivity, among other issues, food is very costly.

According to the World Economic Forum sources, most households in Africa spend over $45 \%$ of their income on basic food consumed in the house (not gourmet food in the restaurants). The figures are as high as $70 \%$ for poor households in most countries. In contrast, households in the USA spend, on average, only $6.5 \%$ of their income on food consumed at home. With these figures, it is evident that subsistence living is not confined to the farmer in rural Kenya. The midlevel fulltime civil servant in Nairobi is also living in the zone of precarious subsistence since he is likely to spend more than $50 \%$ of his salary on feeding his family before paying for housing, transportation, medicine, and other obligations. Countries in which households spend a higher percentage of their income on food face more challenges of chronic food insecurity (in the form of perennial hunger and malnutrition) than those where households spend far less of their income percentage on food. Hence, a third of the billion people living in sub-Saharan Africa reportedly face severe food insecurity, according to the United Nations' Food and Agriculture Organization in its 2018 State of Food Security and Nutrition in the World report.

It is therefore appropriate that the African Archaeological Review's inaugural Usable Pasts Forum focuses on food security. The themes of plant/animal domestication, agricultural origins, and dynamics of food production have been, and will continue to be, an essential 
and healthy part of the archaeological inquiry in Africa. Zooarchaeology, archaeobotany, paleoecology, and different permutations of landscape archaeology have provided excellent insights into Africa's long history of food sourcing strategies, with many more to come in the near future. However, Africanist archaeologists working in these subfields have also been expanding their horizons to focus on the implications and use of archaeological knowledge to reflect on the policies and practices of African agriculture and food sustainability in the present and the prospects for the future (e.g., Davies et al. 2016; Lane 2010; Logan 2017; Stump 2013). The forum contributors in this issue underscore how archaeological empirical research, with long-term and microscale perspectives, can effectively inform the dialogue about the strategies for achieving food security and food sovereignty on the continent. The contributors caution us not to mistake the short-term solutions to prolonged problems that we see in the archaeological record or ethnographic present as evidence of blissful sustainability or resilience. They ask us to interrogate the cost-benefit of those past interventions to understand better how they may be deployed in the considerations of different solutions to the challenges of today and tomorrow. To this end, my special thanks go to Amanda Logan for organizing and leading this inaugural Usable Pasts Forum, aptly titled "Critically Engaging Food Security," and to the other contributors-Steven T. Goldstein, Emuobosa Orijemie, Daryl Stump, and M. H. Schoeman - for using their research and case studies to offer deep and broad discussions on the topic. Cameron Gokee, our associate editor, carried the heavy burden of managing all the logistics of the forum, from submission to review, revision, and production. As always, he did all of these with grace and cheerfulness.

We envisioned the Usable Past Forum as a platform for archaeologists to reflect on the implications of their empirical research findings for a wide range of issues relating to contemporary Africa. The goal is not to issue policy prescriptions or to make archaeology into a magic wand for solving all the ills of the present. Instead, we intend to use the forum to facilitate dialogues on how the deep-time and contextual archaeological knowledge of Africa's past can inform our understanding of the present and African futures, and identify areas of potential collaboration between archaeologists and other professionals and communities in the search for solutions. The raison d'etre of this collaboration is knowledge sharing, and it is based on the acknowledgement of the possibilities and limitations of archaeological interventions in complex issues such as food security. We also know too well that policy discussions about Africa usually take place with a presentist mindset and in frameworks where the African past is vacuous. Unfortunately, the African indigenous knowledge, the main focus of archaeological inquiry, is often missing in policy discussions at the national and international levels (Emeagwali and Shizha 2016). This is why the cabinet adoption of an Indigenous Knowledge Systems (IKS) Policy for South Africa in November 2004 was a significant milestone. It is the most comprehensive blueprint on the continent on how research, policy, curriculum, community engagement, and participatory democracy can be synergized in the use of African IKS for seeking holistic improvement to human lives. The policy adoption in Pretoria was preceded in March 2004 by The Dar es Salaam Declaration that adopts a set of principles on the role that IKS must play for the sustainable development of the Southern African Development Community (SADC) countries. And, IKS is an integral part of the objectives of the New Partnership for Africa's Development (NEPAD), an economic development program of the African Union created in 2001. NEPAD's objectives are to eradicate poverty, promote sustainable growth and development, integrate Africa in the world economy, and accelerate the empowerment of women. None of these goals can be achieved without food security and food sovereignty in national and regional contexts. Archaeologists are well-positioned to support these initiatives at the programmatic, policy, outreach, and curriculum levels, including the education and training of future leaders.

Given the journal's commitment to make archaeology an integral part of the conversation about Africa's present and futures, we plan to distribute the Usable Pasts Forums widely in Africa and elsewhere so that we can inform a diverse cast of constituencies and professionals interested in the issues raised in each forum. Those who care about Africa's present and its future must be mindful of how the African past informs the present, and what the archaeological reconstruction of the past can tell us about a myriad of issues confronting the present. The forum participants underscore the need for archaeologists to be familiar with policies and expertise in other fields. In return, we call upon policy makers, scientists, practitioners, activists, politicians, and national and international technocrats to begin to pay attention to the implications of archaeological knowledge for their respective 
endeavors. We hope that national and local governments, as well as intergovernmental and international institutions, will engage archaeologists to lead workshops for technocrats and policy makers on how deep-time archaeological thinking can inform their work on, for example, agriculture, food security, and landscape management.

Moreover, we hope that the Usable Pasts Forum can play a role in African higher education where archaeology has long been treated as a luxury subject, rarely offered to students in noncognate fields such as agriculture, engineering, political science, and policy studies. This means that generations of scientists and policy makers trained in Africa (not to talk of elsewhere) are mostly uninformed about the critical insights that archaeological knowledge can provide to understanding the present. With a forum like this, we hope the agents of change in African higher education would ensure that archaeological knowledge is infused into the disciplines in the humanities, sciences, social sciences, and professional schools. For example, the fields that drive discussions on food security, from agronomy and food technology to developmental anthropology will benefit from the insights shared in this forum. The concept of "usable past" also has a lot to offer heritage archaeology, a growing component of the curriculum of many archaeology programs in African countries and the United Kingdom. The emphasis on monument and tourism heritage should be balanced with knowledge heritage (IKS) with attentiveness to how the past can inform the search of solutions to the present and evolving challenges.

The theme of food procurement and nourishment runs through this September issue of the journal, from the provisioning of animal products for the Hellenistic Egypt's frontier town of Berenike during the third century BC to the nourishing of Egyptian gods and goddesses with Nubian and Puntite aromatics throughout the pharaonic period. Aromatics were essential to religious worship in ancient Egypt. Thanks to the Nubians, the knowledge of Punt with its rich and precious incenses reached Egypt during the Old Kingdom. The intercultural entanglements, trading networks, regional diplomacy, and political propaganda that shaped the imports of aromatics to Egypt affirm the role of the Nile Valley and the Red Sea as highways of ideas, people, and goods between ancient Egypt and its southern neighbors. We also feature a research report on the strategies and kite-like structures that the ancestral/
Xam San of northwest Nama Karoo bioregion in South Africa used for hunting springbok during the nineteenth and early twentieth centuries. The study demonstrates how the use of the kite-like structures for hunting depended on the mastery of the knowledge of the landscape, seasonality, and astronomy. It throws new light onto our understanding of the Later Stone Age hunting strategies in Southern Africa. This issue of the journal also includes a richly textured review article that examines nearly 60 years of archaeological research in Prospect Farm (Kenya's Central Rift region), one of the best preserved open-air Middle and Later Stone Age sites in Africa. The article elucidates some of the chronostratigraphic problems at the site. It also highlights the vast social networks implicated in the acquisition and curation of obsidian tools used for food procurement (hunting-gathering, in this case) during the Middle Stone Age, as well as the strategic use of different elevation points for food sourcing over several thousands of years.

I trust you will enjoy the assortment of topics and themes covered in this issue. We look forward to receiving proposals for new Usable Pasts Forum topics. Do not hesitate to contact Cameron Gokee or me if you have any questions.

\section{References}

AgroNigeria (2019). President Buhari issues ban on forex for food imports. https://agronigeria.ng/president-buhari-issues-banon-forex-for-food-imports/ [Accessed August 16, 2019].

Davies, M., Folorunso, C. A., Kipruto, T. K., M’Mbogori, F. N., Moore, H. L., Orijemie, E. A., \& Schoeman, A. (2016). The 'useable' archaeology of African farming systems. In K. Sadr, A. Esterhuysen, \& C. Sievers (Eds.), African archaeology without frontiers: Papers from the 2014 PanAfrican Archaeological Association Conference (pp. 1-31). Johannesburg: Wits University Press.

Emeagwali, G., \& Shizha, E. (2016). African indigenous knowledge and the sciences: Journeys into the past and present. Rotterdam: Sense Publishers.

Lane, P. (2010). Developing landscape historical ecologies in Eastern Africa: An outline of current research and potential future directions. African Studies, 69(2), 299-322.

Logan, A. L. (2017). Will agricultural technofixes feed the world? Short- and long-term tradeoffs of adopting high yielding crops. In M. Hegmon (Ed.), The give and take of sustainability: Archaeological and anthropological perspectives (pp. 109-124). New York: Cambridge University Press.

Rakotoarisoa, M. A., Iafrate, M., \& Paschali, M. (2012). Why has Africa become a net food importer?: Explaining Africa agricultural and food trade deficits. Rome: Trade and Markets 
Division, Food and Agriculture Organization of the United Nations.

Shaban, A. R. A. (2017). Why is Africa importing \$35bn in food annually? - AfDB boss asks. africanews. https://www. africanews.com/2017/04/21/why-is-africa-importing-35bnin-food-annually-afdb-boss-asks// [accessed August 18, 2017].
Stump, D. (2013). On applied archaeology, indigenous knowledge, and the usable past. Current Anthropology, 54(3), 268-298.

Publisher's Note Springer Nature remains neutral with regard to jurisdictional claims in published maps and institutional affiliations. 